\title{
Studies on Glucose-6-phosphate Dehydrogenase Deficient Egyptian Families
}

\author{
NEMAT HASHEM* ${ }^{\star}$ and ASSMA NOUR \\ From the Medical Genetics Unit, Ain-Shams University, Cairo, U.A.R.
}

Glucose-6-phosphate dehydrogenase (G6PD) enzyme is a polymorphic enzyme which serves as a good genetic marker. No race is exempt from the G6PD variant types associated with enzyme deficiency (Motulsky and Campbell-Kraut, 1962; Motulsky, 1960), but certain types are found exclusively in certain races. Negroes (Gilles and Taylor, 1961; Robertson, 1961), Mediterraneans (Larizza, Brunetti, and Grignani, 1960; Doxiadis et al., 1961; Salvidio, Pannaccivlli, and Tizianello, 1963), and East Indians (Zinkham, 1959; Choremis, Zannos-Mariolea, and Kattamis, 1962) have a higher incidence of the G6PD deficiency variants, than do pure Orientals (Lee et al., 1963; Jim and $\mathrm{Chu}, 1963$ ) or pure European populations (Erdohazi and Highman, 1962).

Egypt, at the cross-road of three ancient continents, has been invaded many times in the past and has been subjected to free genetic admixture through intermarriage with different races. Ragab, ElAlfi, and Abboud (1966) and Khalil et al. (1966) have supplied evidence for the prevalence of G6PD deficiency among Egyptians. In Herodotus, the Egyptian priests forbade ingestion of fava beans, presumably because of the fear of possible haemolysis (Quoted-Motulsky and Campbell-Kraut 1962). Egyptians, could therefore themselves have been amongst the ancient propagators of the G6PD mutant gene.

In the present study, we postulate the existence of multiple alleles of different functional efficiency for the normal G6PD gene. Prevalence of asymptomatic and symptomatic possessors of either the mild or the severe degrees of G6PD deficiency among Egyptians is discussed. A congenital anomaly encountered among G6PD deficient males is described for the first time.

Received September 3, 1968

$\star$ Present address: 5, El-Goumhouria Street, Cairo, Egypt, U.A.R.

\section{Materials and Methods}

Thirty-five Egyptian children ( 34 males and 1 female) aged 1 to 8 years, examined during a haemolytic crisis caused by G6PD deficiency occurring either spontaneously or precipitated by fava beans, vitamin $K$, sulphonamides, or undefined infections, were used as index cases for quantitative assay of G6PD enzyme in 35 heterozygous mothers, together with 15 of their clinically normal sons and fathers. At the same time, 35 mothers of normal sibships, together with 44 of their sons (aged 8 months to 14 years), were selected in a random fashion from a child welfare centre at AinShams Medical Hospital (Cairo) to serve as controls. In addition, 85 sibs of the patients (65 males aged 1-22 years and 20 females aged 1 week-24 years) and 130 controls (65 mothers aged $22-55$ years and 65 sons aged 1-38 years) were screened for evidence of G6PD deficiency. Controls and G6PD-deficient subjects and their families originated from all districts of both Upper and Lower Egypt.

Full clinical, neurological, and haematological evaluation was carried out for the 35 patients. The quantitative assay of G6PD was performed according to the modification by Motulsky, Vandepitte, and Fraser (1966) of the method of Glock and McLean (1953). G6PD was estimated by plotting the cumulative change in optical density (OD) of the reaction mixture (G6P, triphospho-pyridine nucleotide, buffer solution, and haemolysate). The average OD change is taken as the slope of the line where the increment is constant, and the units are expressed as $\mathrm{OD} / \mathrm{min} . / 100 \mathrm{ml}$. red blood cells (RBC). The screening technique is that of Motulsky and Campbell-Kraut (1962), in which the decolorization time of brilliant cresyl blue (BCB) is checked every 5 minutes for 1 hour after the first 30 minutes and half hourly thereafter.

\section{Results}

Results are shown in Tables I, II, and III, and the Fig.

G6PD enzyme levels among the 35 presumably homozygous Egyptian mothers (as evidenced by clinically normal male offspring, normal brothers, fathers, and uncles) revealed a wide range, 218-840 units, and a mean, $425 \cdot 4 \pm 12 \cdot 3$. When enzyme 
values were arranged in declining order (Table $\mathrm{I}$ ), high enzyme values (Group A, 500-800 units or over, $25.71 \%$ ), intermediate values (Group B, 400499 units, $22.85 \%$, and Group C, 300-399 units, $31.42 \%$ ), and low values (Group D, below 300 units, $20 \%$ ) could be discerned. A similarly wide range of 205 to 740 units, with a somewhat lower mean of $405.0 \pm 11 \cdot 9$, was noted among 42 of their sons, while 2 showed very low G6PD values (25-57 units). No statistically significant difference was noted between the mean enzyme values of mothers or of their sons in any of the four subgroups.

G6PD enzyme values of the 35 heterozygous mothers ranged between 127 and 380 units, with a mean of $224 \pm 11.53$; a value evidently far below that of homozygous mothers. In $40 \%$, G6PD values overlapped with $40 \%$ of those of normal homozygous mothers (17\% of Group C and $23 \%$ of
Group D), and in $60 \%$ it amounted to $54: 97 \%$ of their lowest value. Of the 44 clinically normal sons, there were 2 who revealed very low G6PD enzyme levels: these belonged to 2 presumed normal but proven heterozygous mothers with G6PD enzyme values in the $40 \%$ overlapping range (Table I).

When G6PD enzyme levels of normal sons were compared with those of their homozygous normal mothers, a marked intrafamilial similarity of enzyme level was noted among sons and between sons and mothers when mothers had high enzyme values (Table I Group A, Cases 3, 4, 7, 8). However, a tendency to bimodality, with both low and high enzyme values, was noted among sons of mothers who had intermediate enzyme values (Table I, Cases 11, 16, 19). Almost all sons of normal homozygous mothers with low G6PD levels had

TABLE I

G6PD ENZYME LEVELS (Unit $=\triangle O D / \mathrm{min} . / 100 \mathrm{ml}$. RBC) IN EGYPTIAN WOMEN AND THEIR SONS

\begin{tabular}{|c|c|c|c|c|c|c|c|}
\hline Group & $\begin{array}{l}\text { Case } \\
\text { No. }\end{array}$ & $\begin{array}{c}\text { Presumably } \\
\text { Homozygous } \\
\text { Mothers }\end{array}$ & \multicolumn{3}{|c|}{$\begin{array}{l}\text { Clinically Normal } \\
\text { Sons }\end{array}$} & $\begin{array}{c}\text { Heterozygous } \\
\text { Mothers }\end{array}$ & $\begin{array}{c}\text { G6PD } \\
\text { Deficient Sons }\end{array}$ \\
\hline A & $\begin{array}{l}1 \\
2 \\
3 \\
4 \\
5 \\
6 \\
7 \\
8 \\
9\end{array}$ & $\begin{array}{l}840 \\
740 \\
717 \\
688 \\
656 \\
550 \\
548 \\
503 \\
502\end{array}$ & & $\begin{array}{l}678 \\
550 \\
740 \\
720 \\
494 \\
410 \\
550 \\
529 \\
415\end{array}$ & $\begin{array}{r}615 \\
528 \\
\\
487 \\
674\end{array}$ & $\begin{array}{l}380^{\star} \\
364^{\star} \\
355^{\star} \\
346^{\star} \\
331^{\star} \\
320^{\star} \\
286^{\star} \\
281^{\star} \\
281^{\star}\end{array}$ & $\begin{array}{r}57 \\
36 \\
107 \\
0 \\
198+ \\
20 \\
0 \\
0 \\
45\end{array}$ \\
\hline B & $\begin{array}{l}10 \\
11 \\
12 \\
13 \\
14 \\
15 \\
16 \\
17\end{array}$ & $\begin{array}{l}484 \\
454 \\
434 \\
412 \\
404 \\
400 \\
400 \\
400\end{array}$ & & $\begin{array}{l}398 \\
498 \\
458 \\
472 \\
389 \\
375 \\
494 \\
368\end{array}$ & 208 & $\begin{array}{l}281^{\star} \\
278^{\star} \\
250^{\star} \\
233^{\star} \\
219^{\star} \\
212 \\
206 \\
200\end{array}$ & $\begin{array}{r}0 \\
70 \\
47 \\
32 \\
0 \\
25 \\
30 \\
50\end{array}$ \\
\hline C & $\begin{array}{l}18 \\
19 \\
20 \\
21 \\
22 \\
23 \\
24 \\
25 \\
26 \\
27 \\
28\end{array}$ & $\begin{array}{l}393 \\
390 \\
387 \\
387 \\
381^{\star} \\
375^{\star} \\
363^{\star} \\
360^{\star} \\
334^{\star} \\
325^{\star} \\
306^{\star}\end{array}$ & 280 & $\begin{array}{l}332 \\
415 \\
394 \\
359 \\
355 \\
265 \\
269 \\
354 \\
300 \\
276 \\
364\end{array}$ & 243 & $\begin{array}{l}198 \\
195 \\
191 \\
190 \\
189 \\
186 \\
182 \\
180 \\
179 \\
179 \\
175\end{array}$ & $\begin{array}{c}46 \\
25 \\
3 \\
29 \\
247 \dagger \\
25 \\
0 \\
55 \\
23 \\
27 \\
52\end{array}$ \\
\hline \multirow[t]{2}{*}{$\mathrm{D}$} & \multirow[t]{2}{*}{$\begin{array}{l}29 \\
30 \\
31 \\
32 \\
33 \\
34 \\
35\end{array}$} & $\begin{array}{l}285^{\star} \\
281^{\star} \\
260^{\star} \\
252^{\star} \\
233^{\star} \\
228^{\star} \\
218^{\star}\end{array}$ & & $\begin{array}{r}57 \\
209 \\
25 \\
219 \\
340 \\
205 \\
276\end{array}$ & & $\begin{array}{l}160 \\
150 \\
145 \\
132 \\
130 \\
129 \\
127\end{array}$ & $\begin{array}{r}44 \\
0 \\
0 \\
32 \\
45 \\
27 \\
0 \text { Ferrale }\end{array}$ \\
\hline & & $\begin{aligned} & \text { Range }=840-218 \\
& S D \mp 151 \cdot 5 \\
& \text { Mean }= 425 \cdot 4 \\
& S E \pm 12 \cdot 3\end{aligned}$ & \multicolumn{3}{|c|}{$\begin{aligned} \text { Range }= & 740-205 \\
& S D \mp 143.8 \\
\text { Mean }= & 405.0 \\
& S E \pm 11.9\end{aligned}$} & $\begin{aligned} \text { Range }= & 380-127 \\
& S D \mp 132 \cdot 8 \\
\text { Mean }= & 224 \cdot 0 \\
& S E \pm 11.53\end{aligned}$ & \\
\hline
\end{tabular}

^ Overlapping range of G6PD values between heterozygous and presumably homozygous females.

† Assay done 10 days after a second haemolytic crisis. 
TABLE II

G6PD ENZYME LEVEL OF FEMALES, THEIR NORMAL SONS AND NORMAL FATHERS

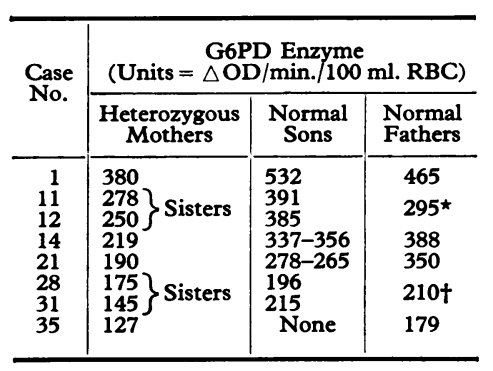

* Father of Cases 11 and 12.

† Father of Cases 28 and 31. EGYPTIAN HETEROZYGOUS

low enzyme values, excluding the 2 sons with very low enzyme values (Table 1, Cases 29 and 31) who were shown to belong to masked heterozygous mothers.

When G6PD enzyme levels of normal sons and normal fathers of 8 mothers heterozygous for G6PD deficiency gene were compared, a striking quantitative similarity was noted among them. In addition, the enzyme values of the 8 heterozygous mothers correlated significantly with those of their normal sons and fathers $(r=+0.96-p<0.01$ and $r=+0.745-p=<0.05)$, though they were persistently lower (Table II).

Table III illustrates the results of BCB screening test and some simultaneous G6PD enzyme assays in patients, controls, their sibs, and mothers.

TABLE III

BRILLIANT CRESYL BLUE DYE TEST FOR G6PD IN AFFECTED AND CONTROL FAMILIES

\begin{tabular}{|c|c|c|c|c|c|c|c|c|c|c|c|c|c|c|}
\hline \multirow{2}{*}{ Study Groups } & \multicolumn{13}{|c|}{ Minutes Required for Decolorization } & \multirow{2}{*}{ Total } \\
\hline & 30 & 35 & 40 & 45 & 50 & 55 & 60 & 70 & 80 & 90 & 120 & 180 & 180 & \\
\hline $\begin{array}{l}\text { Males } \\
\text { Patients and their } \\
\text { sibs } \\
\text { Controls }\end{array}$ & $\bar{I}$ & $\begin{array}{l}2 \\
6\end{array}$ & $\begin{array}{r}4 \\
32\end{array}$ & $\begin{array}{l}4 \\
9\end{array}$ & $\begin{array}{r}10 \\
8\end{array}$ & $\begin{array}{l}21 \\
16\end{array}$ & $\begin{array}{r}4 \\
16\end{array}$ & $\begin{array}{l}6 \\
4^{\star}\end{array}$ & $\begin{array}{l}5 \\
\text { I }\end{array}$ & $\begin{array}{l}5^{\star} \\
2^{\star}\end{array}$ & $\begin{array}{l}\text { 5t } \\
\text { If }\end{array}$ & $\begin{array}{r}20 \dagger \\
2 \ddagger\end{array}$ & $\begin{array}{r}14 \dagger \\
2 \S\end{array}$ & $\begin{array}{l}100 \\
100\end{array}$ \\
\hline Total & & & & & & & & & & & & & & 200 \\
\hline $\begin{array}{l}\text { Females } \\
\text { Mothers of patients } \\
\text { and their daughters } \\
\text { Mothers of controls }\end{array}$ & $=$ & $\overline{\text { II }}$ & $\overline{27}$ & $\begin{array}{r}3 \\
16\end{array}$ & $\begin{array}{r}8 \\
18\end{array}$ & $\begin{array}{r}5 \\
10\end{array}$ & $\begin{array}{r}14 \\
3\end{array}$ & $\begin{array}{l}10 \\
8^{\star}\end{array}$ & $\begin{array}{l}6 \pi \\
3^{\star}\end{array}$ & $\begin{array}{l}51 \\
4^{\star}\end{array}$ & I & 二 & $\begin{array}{l}2^{\star \star} \\
p\end{array}$ & $\begin{array}{r}55 \\
100\end{array}$ \\
\hline Total & & & & & & & & & & & & & & 155 \\
\hline
\end{tabular}

Enzyme values of 2:5 members representing the six-time intervals exceeding 60 minutes.

* Enzyme values, 375-233 units.

† Sibs having G6PD deficiency + microcephaly in pedigrees F2, F3, F4, F7-F9 (Fig.) Enzyme values, 0-3-20 units.

¥ Moderate grade of neonatal jaundice in pedigree F6 (Fig.). Enzyme values, 57-25 units.

s Silent G6PD deficiency in pedigrees F1 and F5 (Fig.). Enzyme values, 10-23-40 units.

Tा Enzyme values, 145-285.

$\star \star$ Two females sibs in pedigree F8 (Fig.) who developed severe neonatal jaundice. Enzyme values, zero.

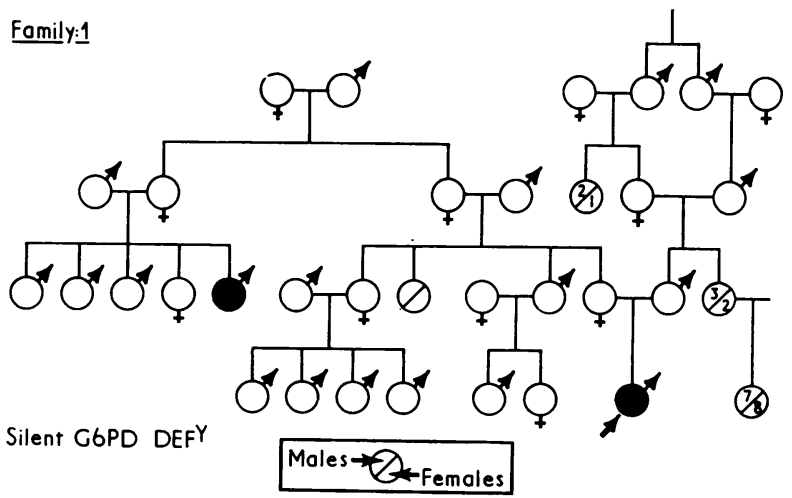

(A)

Fig. A-I. Solid symbols

G6PD deficient members; D-died; PP and MP in F:3 signify paterno-paternal and materno-paterna 1 first cousin parents. Symbols (1) indicate 1 male, 1 female. 
Studies on Glucose-6-Phosphate Dehydrogenase Deficient Egyptian Families

153

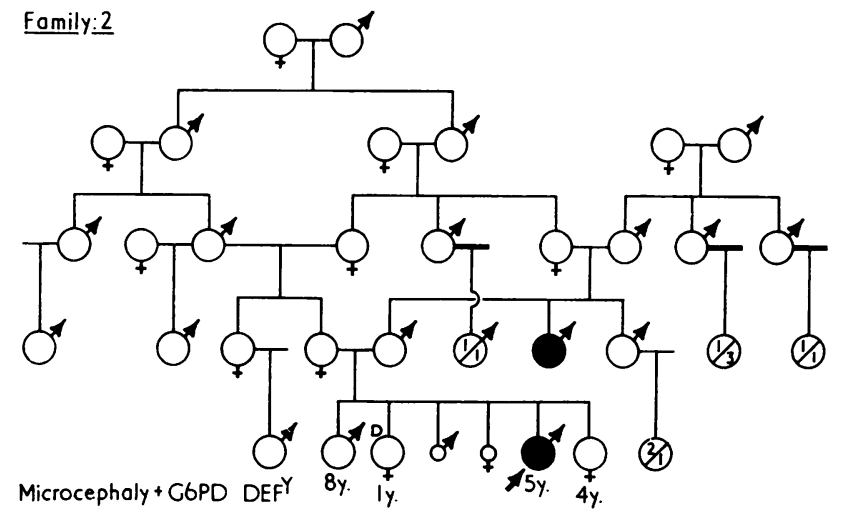

(B)

Fomily: 3

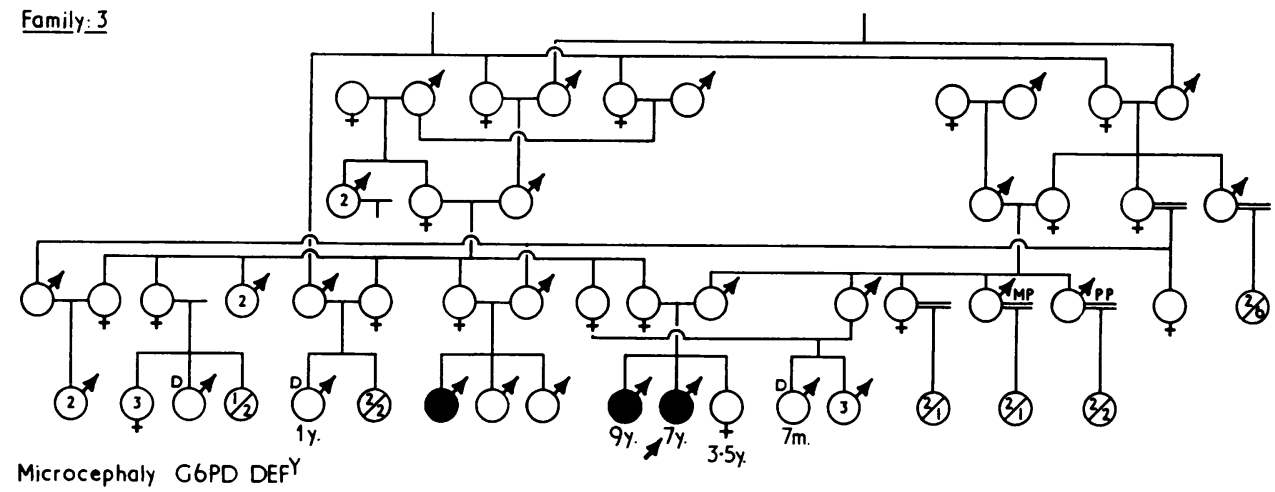

Microcephaly G6PD DEFY

(C)

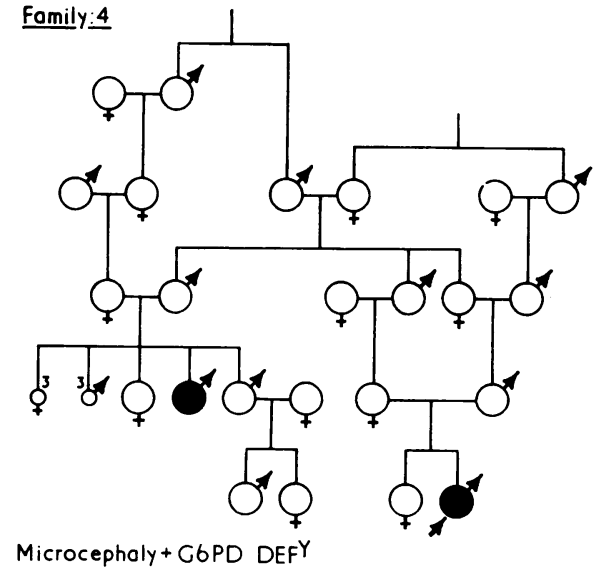

(D)

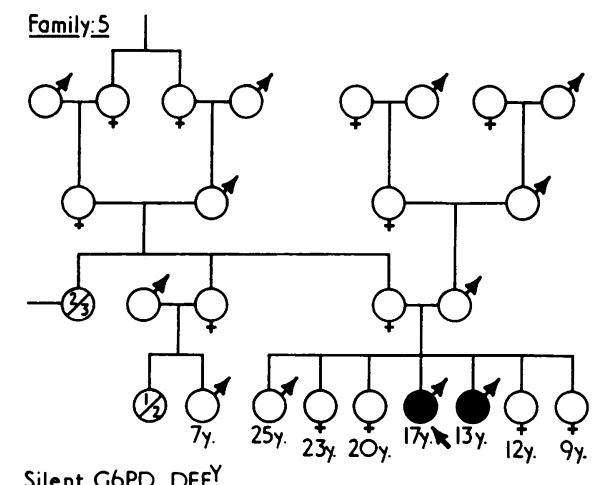

Silent G6PD DEFY

(F) 


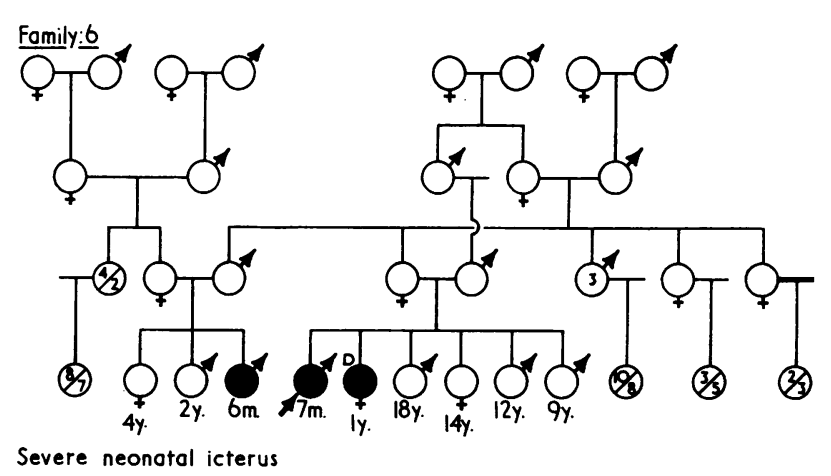

(F)

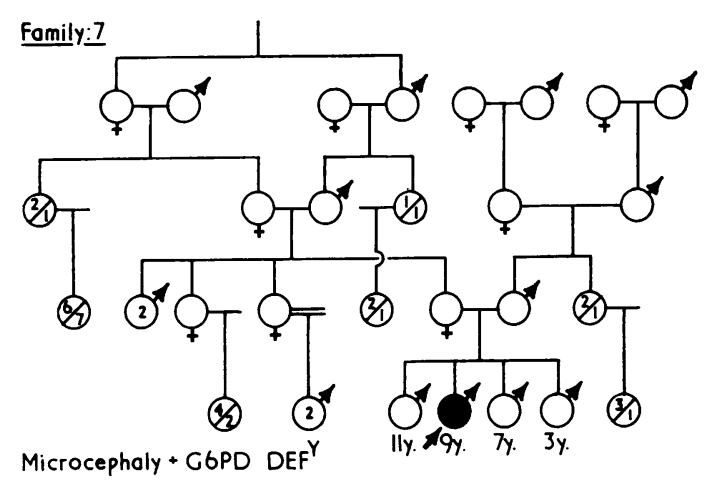

(G)

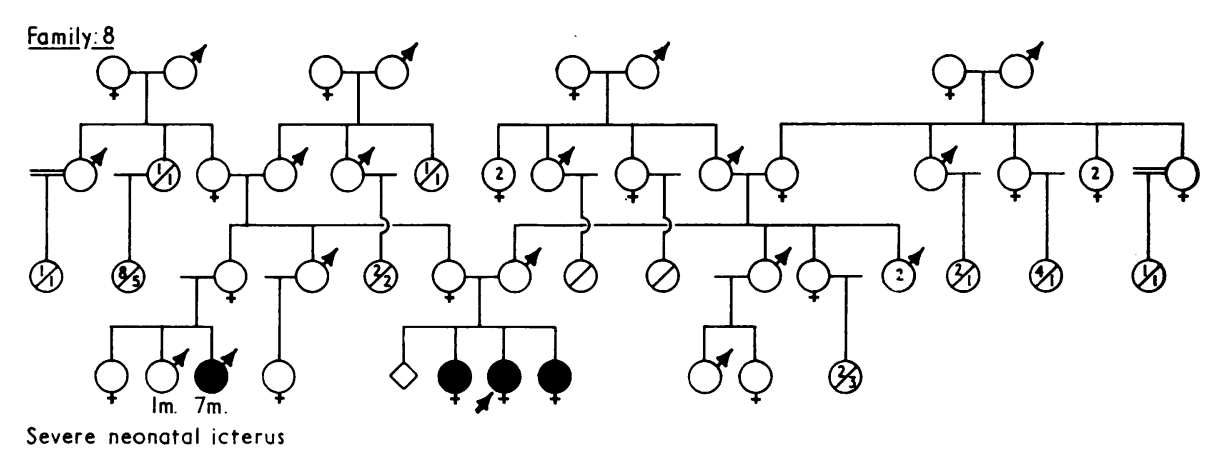

(H) 


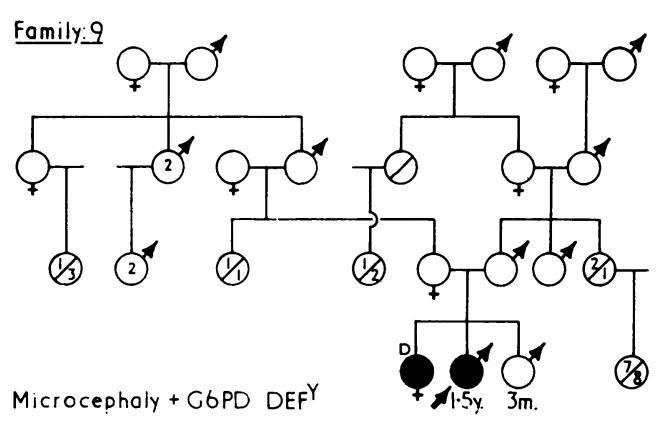

(I)

The Fig. illustrates an example of the pedigree pattern encountered among G6PD enzyme deficient families included in the present study. First and second cousinship consanguinity among parents of propositi is present in $35 \%$ of both patients and control groups. In pedigrees of each of the families (Cases 2, 3, 4, 7, 9) one male propositus showed, in addition to G6PD deficiency, congenital microcephaly, gross mental deficiency (IQ 20-45), spastic cerebral palsy, and generalized major motor epilepsy. A female sib (Case 9) also presented with the same neurological disorder but died of pneumonia before G6PD assay could be undertaken.

\section{Discussion}

The wide quantitative variation in G6PD enzyme level detected in normal homozygous females (218840 units) and their normal sons (205-740 units), together with the significant correlation $(r=+0.52$, $p=<0.01)$ between enzyme values of mothers and their respective sons (Table I), point to a genetically determined variation in normal G6PD enzyme level. It is possible that the G6PD enzyme locus possesses a series of alleles, and if each allele has a different efficiency in promoting G6PD enzyme synthesis, it would reflect a different normal enzyme level. The proof for such a hypothesis stems from several preliminary findings. Enzyme levels of normal sons of homozygous normal mothers with high G6PD levels had comparably high G6PD levels, while the enzyme levels of normal sons of homozygous normal mothers with intermediate enzyme levels displayed a bimodal distribution with low and high enzyme values among different sons within families (Table I). In addition, G6PD enzyme values of normal sons and normal fathers of mothers heterozygous for the
G6PD deficiency gene, as well as depicting a striking similarity in their levels, showed significant correlation with the mothers' values (Table II). Though G6PD enzyme values of heterozygous mothers were invariably less than those of their normal sons or fathers, they also covered a wide range (380-127 units), with $40 \%$ of their values overlapping values encountered among normal homozygous mothers. Such wide yet lower enzymatic ranges can also be interpreted as due to operation of G6PD enzyme alleles of variable functional efficiency, which have furthermore been subjected to random alternate inactivation with the G6PD mutant gene in the heterozygous mothers. The implication of such a hypothesis is that it provides a means for identification of heterozygous females for mutant G6PD enzyme or other Xlinked traits. In a family with a proved heterozygous mother, an intrafamilial discrepancy in G6PD enzyme values with high levels in father and sons and intermediate or low levels in daughters could imply heterozygosity of daughters, provided their enzyme values are significantly lower than their father's.

The detection of very low G6PD enzyme values among sons of 2 of the 35 presumably normal homozygous mothers, with enzyme levels in the overlapping range between homozygosity and heterozygosity, indicates a prevalence of the G6PD enzyme deficiency gene (q) among Egyptian male controls included in the present sample to be 0.0571 , and that of heterozygous females (2pq) to be $0 \cdot 1076$. The 0.0571 gene frequency was further verified when the screening survey using BCB dye test was extended to include 100 normal sons and their presumably homozygous mothers. BCB failed to decolorize within 90 minutes (the accepted maximum normal time limit) in only $5 \%$ of the sons. However, its efficiency for heterozygous detection was not proved in the present study. The time interval $60-90$ minutes was thought to be optimal for heterozygous detection, as normal males and females whose samples decolorized within this time interval had enzyme values in the heterozygous range (145-385 units). However, among 100 normal control mothers, BCB test gave an incidence of $15 \%$ heterozygous instead of $11 \%$ which was expected according to the Hardy-Weinberg law $(2 \mathrm{pq}=0 \cdot 1076)$. Further, in a series of 35 proven heterozygous females and 17 of their normal female offspring, the test spotted 21 or $40 \%$ instead of the 43 or $84 \%$ incidence expected. Thus, an overestimate of $29 \%$ heterozygous incidence was obtained in one group and an underestimate of $51 \%$ in another (Table III). 
G6PD enzyme deficiency, as well as presenting with acute haemolytic crisis in the majority of patients in the present study, presented in two families with severe icterus neonatorum (F: 6 and 8, Fig.). In 7 male sibs (aged 3-14 years) of G6PD deficient patients in whom enzyme assay revealed marked deficiency (range $=10-40$ units), the deficiency remained asymptomatic though they were subjected to the same factors that precipitated the haemolytic crises in their sibs (F: 1 and 5 Fig., and Table III), and evidently they possessed the same enzyme variant.

The 5 male patients who, in addition to G6PD deficiency, displayed congenital microcephaly, mental deficiency, spastic cerebral palsy, and generalized major motor epilepsy (and simian crease in 2 patients), seem to have inherited this cerebro-cranial anomaly as an X-linked trait. Patients encountered with the neurological sequelae of neonatal bilirubin encephalopathy never exhibit this degree of microcephaly nor such epileptic manifestations, and the motor deficit is consequent mostly to basal ganglia, and may be a cerebellar deficit. The fact that another male member of pedigree (F: 3, Fig.) had G6PD deficiency only, while a female sib (F: 9, Fig.) presented with the neurological syndrome, suggests that, though the two traits may be $\mathrm{X}$-linked yet their gene loci are not linked, and the neurological syndrome seems to have variable penetrance.

\section{Summary}

Evidence is produced for a hypothesis which assumes the existence of a series of alleles with varying efficiency in mediating G6PD synthesis. Besides presenting as acute haemolytic crises or severe icterus neonatorum, the prevalence of silent G6PD deficiency among Egyptians is stressed. The incidence of the G6PD deficiency gene among Egyptian male controls in the present sample is $6 \%$ and that of heterozygous females is $11 \%$. A cranio-cerebral congenital anomaly associated with
G6PD deficiency encountered among 5 male patients is described for the first time.

This study has been assisted by a grant from National Institutes of Health, U.S.A., and by the Association for Aid of Crippled Children, U.S.A.

\section{REFERENCES}

Choremis, G., Zannos-Mariolea, L., and Kattamis, M. D. C. (1962) Frequency of glucose-6-phosphate-dehydrogenase deficiency in certain highly malarious areas of Greece. Lancet, 1, 17.

Doxiadis, S. A., Fessas, Ph., Valaes, T., and Mastrokalos, N. (1961) Glucose-6-phosphate dehydrogenase deficiency. A new aetiological factor of severe neonatal jaundice. ibid., 1, 297.

Erdohazi, M., and Highman, W. J. (1962). Glucose-6-phosphatedehydrogenase deficiency in Britain. ibid., 2, 1274.

Gilles, H: M., and Taylor, B. G. (1961). The existence of the glucose-6-phosphate dehydrogenase deficiency trait in Nigeria and its clinical implications. Ann. trop. Med. Parasit., 55, 64.

Glock, G. K., and McLean, P. (1953). Further studies on the properties and assay of glucose-6-phosphate-dehydrogenase and 6phosphogluconate dehydrogenase of rat liver. Biochem. $\mathcal{f}$., 55, 400.

Jim, R. T. S., and Chu, F. K. (1963). Hyperbilirubinemia due to glucose-6-phosphate dehydrogenase deficiency in a newborn Chinese infant. Pediatrics, 31, 1046.

Khalil, M., Ibrahim, A. H., El-Khateeb, S., Aref, K., Gabr, Y., and Amin, N. (1966). Studies on erythrocytic glucose-6-phosphate dehydrogenase activity. f. trop. Med. Hyg., 69, 264.

Larizza, P., Brunetti, P., and Grignani, F. (1960). Anemie emolitiche enzimopenche. Haematologica, 45, 129.

Lee, T. C., Shih, L. Y., Huang, P. C., Lin, C. C., Blackwell, B. N., Blackwell, R. Q., and Hsia, D. Y. (1963). Glucose-6-phosphate dehydrogenase deficiency in Taiwan. Amer. F. hum. Genet., 15, 126.

Motulsky, A. G. (1960). Metabolic polymorphisms and the role of infectious diseases in human evolution. Hum. Biol., 32, 28.

, and Campbell-Kraut, T. M. (1962). Population genetics of glucose-6-phosphate dehydrogenase deficiency of the red cell. In Proc. Conf. Genetic Polymorphisms and Geographic Variations in Diseases, pp. 188 and 159. Grune and Stratton, New York.

-, Vandepitte, J., and Fraser, G. R. (1966). Population genetic studies in the Congo. I. Glucose-6-phosphate dehydrogenase deficiency, hemoglobin S, and malaria. Amer. F. hum. Genet., 18 , 514.

Ragab, A. H., El-Alfi, O. S., and Abboud, M. A. (1966). Incidence of glucose-6-phosphate-dehydrogenase in Egypt. ibid., 18, 21.

Robertson, D. H. H. (1961). Nitrofurazone-induced haemolytic anaemia in a refractory case of trypanosoma rhodesiense sleeping sickness: The haemolytic trait and self-limiting haemolytic anaemia. Ann. trop. Med. Parasit., 55, 49.

Salvidio, E., Pannaccivlli, I., and Tizianello, A. (1963). G-6-P-D deficient states in Sardinians. Proc. IX cong Europ. Soc. Hem. Lisbon, Part 11/1, p. $707 . \quad$ S. Karger, Basel.

Zinkham, W. H. (1959). An in-vitro abnormality of glutathione metabolism in erythrocytes from normal newborns: mechanism and clinical significance. Pediatrics, 23, 18. 